\title{
Menyelami Asas Ultra Petita Dalam Putusan Dewan Kehormatan Penyelengara Pemilu
}

\section{"Understanding The Ultra Petita In The Decision of The General Election Honors Board"}

\author{
Janwar Hippy ${ }^{1}$ \\ Sudarsono $^{2}$ \\ Istislam $^{3}$
${ }^{1}$ Magister Ilmu Hukum, Program Pasca Sarjana Universitas Brawijaya, Malang, Indonesia. Email
2 Fakultas Hukum Universitas Brawijaya, Malang, Indonesia.
${ }^{3}$ Fakultas Hukum Universitas Brawijaya, Malang, Indonesia.

\section{Info Artikel}

\section{Kata Kunci:}

Ultra Petita; Putusan;

Dewan Kehormatan

Penyelenggara Pemilu.

Cara Mengutip (APA

Citation Style):

Hippy, Janwar,

Sudarsono, dan Istislam. (2020). "Menyelami Asas

Ultra Petita Dalam

Putusan Dewan

Kehormatan

Penyelengara Pemilu

(DKPP)". Jambura Law Review, JALREV 2 (1): 48-64

\begin{abstract}
Abstrak
Putusan DKPP Nomor 88/DKPP-PKE-IV/2015 memutus lebih dari yang diminta oleh pengadu (menerapkan asas ultra petita). Padahal, DKPP merupakan salah satu organ tata usaha negara yang berfungsi sebagai lembaga peradilan etik, bukan lembaga peradilan hukum. Melalui UU Penyelenggara Pemilu, terbentuk lembaga Dewan Kehormatan Penyelenggara Pemilu (DKPP) yang dikhususkan untuk mengimbangi serta mengawasi kinerja Komisi Pemilihan Umum dan Badan Pengawas Pemilu. Selayaknya penggunaan asas-asas yang notabene hanya dipakai di dalam lingkungan lembaga peradilan yang di akui di Indonesia, tidak serta merta diterpakan oleh DKPP dalam putusannya. Tulisan ini akan menjelaskan kajian mengenai penggunaan asas ultra petita dalam putusan DKPP yang pada dasarnya hanya memiliki fungsi sebagai peradilan etik. Penelitian ini menggunakan metode yuridis normatif dengan pendekatan perundangundangan (statue approach), pendekatan kasus (case approach) dan pendekatan konseptual (conseptual approach). Hasil penelitian ini adalah; 1) Penggunaan asas ultra petita oleh DKPP dalam memutus pelanggaran kode etik oleh penyelenggara Pemilu (KPU dan Bawaslu) tidak bertentangan dengan hukum positif yang berlaku, karena telah ditentukan batasan kewenangan putusan DKPP dalam UU Pemilu.. 2) Terdapat dua akibat hukum putusan DKPP yang menerapkan asas ultra petita antara lain KTUN penyelenggara Pemilu sah dan mengikat, dan cacat hukum (batal dan tidak sah).
\end{abstract}




\section{Article Info}

\section{Keywords:}

Ultra Petita; Decision; General Election Honors Board.

How to cite (APA Citation Style):

Hippy, Janwar, Sudarsono, dan Istislam. (2020).

"Understanding The Ultra Petita In The Decision Of The Board Of Honors of The General Election". Jambura Law Review,JALREV 2 (1): 48-64

\begin{abstract}
The general election honors board's Decision Number 88 / DKPP-PKE-IV / 2015 decides more than requested by the complainant (applies the ultra petite principle). The general election honors board is one of the state administrative organs that functions as an ethical justice institution, not a legal justice institution. Through the Election Organizing Law, an Election Organizing Honorary Board was formed which was devoted to compensating and overseeing the performance of the General Election Commission and the Election Supervisory Body. The use of principles that are only used within a judicial institution recognized in Indonesia does not necessarily apply to the general election honors board in its decision. This paper will explain the study of the use of the principle of ultra petite in the general election honors board decision which only has the function as an ethical court. This study uses a normative juridical method with a statute approach, a case approach and a conceptual approach. The results of this study are; 1) The use of the principle of ultra petita by the general election honors board in deciding violations of the code of ethics by the election organizers does not conflict with the positive law in force, because the authority of the general election honors board's decision has been determined in the Election Law. 2) There are two legal consequences of the The general election honors board's ruling, applying the principle of ultra petita, among others, the state administrative council decisions, which organizes the General Elections is valid and binding and is invalid (null and invalid).
\end{abstract}




\section{Pendahuluan}

Perkembangan zaman serta runtuhnya orde baru ke orde reformasi membawa perubahan dalam pelaksanaan Pemilu di Indonesia. Dinamika Pemilu di Indonesia dapat dilihat dalam undang-undang Pemilu dari masa ke masa. Undang-Undang Nomor 15 Tahun 2011 tentang Penyelenggara Pemilihan Umum (untuk selanjutnya disebut UU Penyelenggara Pemilu) menjadi dasar hukum penyelenggaraan Pemilu yang berkualitas dan menjamin pelaksanaan hak politik masyarakat. ${ }^{1}$ Melalui UU Penyelenggara Pemilu, dibentuk lembaga baru yang dikhususkan untuk mengimbangi serta mengawasi kinerja Komisi Pemilihan Umum (untuk selanjutnya disebut KPU) dan Badan Pengawas Pemilu (untuk selanjutnya disebut Bawaslu) yaitu Dewan Kehormatan Penyelenggara Pemilu (DKPP).

Pada periode Pemilu 2009 dan sebelumnya, penyelenggara Pemilu hanya terdiri dari KPU sebagai lembaga pelaksana (body of execution) dan Bawaslu sebagai lembaga pengawasan (body of control), dengan lahirnya UU Penyelenggara Pemilu hadir pula DKPP sebagai lembaga mahkamah internal (quasi judicial body), dengan kata lain pelaksana pemilu adalah suatu lembaga yang merupakan rumpun dari ketiga organ lembaga internal tersebut yang melaksanakan fungsi saling mengimbangi dan mengendalikan secara internal (check and balances) untuk menghasilkan penyelenggaraan Pemilu yang baik. ${ }^{2}$

DKPP adalah lembaga yang bertugas menangani pelanggaran kode etik Penyelenggara Pemilu (KPU dan Bawaslu). ${ }^{3}$ Setelah pada tahun 2017, diundangkan Undang-Undang Nomor 7 Tahun 2017 tentang Pemilu (untuk selanjutnya disebut UU Pemilu), UU Pemilu menjadi dasar hukum penyelenggara Pemilu salah satunya ialah DKPP.

DKPP adalah organ tata usaha negara (TUN), bukan lembaga peradilan sebagaimana dimaksud dalam Pasal 24 UUD NRI Tahun 1945 yang memiliki kekuasaan yang

\footnotetext{
${ }^{1}$ Konsideran Menimbang huruf a dan b Undang-Undang Nomor 7 Tahun 2017 tentang Penyelenggaraan Pemilihan Umum.

2 Keterangan DPR RI, dalam Putusan Mahkamah Konstitusi Nomor 31/PUU-XI/2013. Hal. 50.

${ }^{3}$ Pasal 1 angka 24 Undang-Undang Nomor 7 Tahun 2017 tentang Penyelenggaraan Pemilihan Umum. Agustus 2017 telah disahkan Undang-Undang Nomor 7 Tahun 2017 tentang Pemilihan Umum (untuk selanjutnya disebut UU Pemilu).
} 
merdeka untuk menegakan hukum dan keadilan. ${ }^{4}$ DKPP tidak termasuk dalam pengadilan khusus yang masuk dalam salah satu lingkungan peradilan di bawah MA sebagaimana dimaksudkan oleh Pasal 24 ayat (2) UUD NRI Tahun 1945 dan Pasal 27 ayat (1) Undang-Undang Nomor 48 Tahun 2009 tentang Kekuasaan Kehakiman serta tidak termasuk pula sebagai salah satu pelaku kekuasaan kehakiman sebagaimana dimaksud Pasal 24 ayat (2) UUD $1945 .^{5}$

Dengan demikian, seyogyanya penggunaan asas-asas yang notabene hanya dipakai di dalam lingkungan lembaga peradilan yang di akui di Indonesia, tidak serta merta diterpakan oleh DKPP dalam putusannya. DKPP merupakan salah satu lembaga yang diinstitusionalisasikan dalam UU Pemilu. Lembaga ini mempunyai tugas dan kewenangan yang berkaitan dengan orang per orang pejabat penyelenggara pemilihan umum, baik KPU dan Bawaslu. ${ }^{6}$

Sebagaimana ditegaskan di atas, DKPP merupakan lembaga etik bukan lembaga peradilan maka seharusnya penggunaan asas-asas yang dipakai dalam lingkungan lembaga peradilan tidak serta merta dipakai dalam lingkungan lembaga etik DKPP. Seperti halnya yang terjadi dalam Putusan DKPP Nomor 88/DKPP-PKE-IV/2015 terhadap Pelanggaran Kode Etik Bawaslu Provinsi Gorontalo. Dalam Pelanggaran Kode Etik ini, DKPP menggunakan Asas ultra petita dalam memberikan putusan terhadap pelanggaran etik yang diadukan ke DKPP.

Asas ultra petita merupakan asas yang hanya dapat digunakan secara limitatif di lembaga peradilan. Sebaliknya, DKPP yang bukan merupakan lembaga peradilan menggunakan asas ultra petita dalam memutus pelanggaran etik. Hal ini dapat dilihat dalam putusan DKPP yang amar putusannya memerintahkan Sekretaris Jenderal Badan Pengawas Pemilihan Umum Republik Indonesia untuk mengembalikan Burhanuddin Alpiah selaku Kepala Sekretariat Bawaslu Provinsi Gorontalo ke

\footnotetext{
4 Putusan Mahkamah Konstitusi Nomor 115/PHPU.D-XII/2013, tanggal 1 Oktober 2013.

5 Pertimbangan Mahkamah Konstitusi dalam Putusan Mahkamah Konstitusi Nomor 31/PUU-XI/2013. Hal. 70

6 Jimly Asshiddiqie. Makalah: “Pengenalan Tentang DKPP Untuk Penegak Hukum”. Disampaikan dalam forum Rapat Pimpinan Kepolisian Republik Indonesia di Jakarta pada Februari 2013
} 
Pemerintahan Daerah Provinsi Gorontalo, dan melakukan evaluasi menyeluruh terhadap jajaran Sekretariat Bawaslu Provinsi Gorontalo. ${ }^{7}$

Ultra petita adalah penjatuhan putusan oleh hakim atas perkara yang tidak dituntut atau melebihi dari pada yang diminta ${ }^{8}$. Ketentuan ultra petita diatur dalam Pasal 178 ayat (2) dan (3) Het Herziene Indonesisch Reglement (HIR) serta padanannya dalam Pasal 189 ayat (2) dan (3) RBg yang melarang seorang hakim memutus melebihi apa yang dituntut (petitum) Ketentuan HIR merupakan hukum acara yang berlaku di pengadilan perdata di Indonesia.

Ultra petita dalam hukum formil mengandung pengertian penjatuhan putusan atas perkara yang tidak dituntut atau meluluskan lebih dari pada yang diminta. Dalam Putusan DKPP Nomor 88/DKPP-PKE-IV/2015, Petitum yang telah dimohonkan oleh Pengadu dalam hal ini Ramdhan Kasim tidak terdapat permohonan untuk mengembalikan sebagaimana diatas. Dalam Petitum-nya, Ramdhan kasim hanya memohonkan beberapa hal berikut ${ }^{9}$ :

1) Menyatakan Teradu (Hasyim Wantu selaku Ketua Bawaslu Provinsi Gorontalo) telah melakukan pelanggaran Kode Etik

2) Memberikan sanksi pemberhentian tetap sesuai dengan ketentuan Peraturan Perundang-Undangan atas Pelanggaran Kode Etik yang dilakukan Teradu, dan

3) Jika Majelis Dewan Kehormatan Penyelenggaraan Pemilu berpendapat lain mohon putusan yang seadil-adilnya sesuai dengan Pertauran PerundangUndangan yang berlaku.

Sebaliknya, DKPP dalam putusannya Nomor 88/DKPP-PKE-IV/2015 memutus lebih dari yang diminta oleh pengadu. Putusan DKPP memerintahkan Sekretaris Jenderal Badan Pengawas Pemilihan Umum Republik Indonesia untuk mengembalikan Burhanuddin Alpiah selaku Kepala Sekretariat Bawaslu Provinsi Gorontalo ke Pemerintahan Daerah Provinsi Gorontalo, dan melakukan evaluasi menyeluruh terhadap jajaran Sekretariat Bawaslu Provinsi Gorontalo. ${ }^{10}$ Padahal, kewenangan

\footnotetext{
7 Putusan poin 4 dalam Putusan DKPP Nomor 88/DKPP-PKE-IV/2015 terhadap Pelanggaran Kode Etik Bawaslu Provinsi Gorontalo.

8 Ibnu Sina Chandranegara. (2012). "Ultra petita Dalam Pengujian Undang-undang dan Jalan Mencapai Keadilan Konstitusional”. Jurnal Konstitusi. Vol 9 No 1 Maret 2012: 28.

${ }^{9}$ Petitum Pengaduan Nomor 186/I-P/L-DKPP/2015 tanggal 27 Oktober 2015

10 Putusan poin 4 dalam Putusan DKPP Nomor 88/DKPP-PKE-IV/2015 terhadap Pelanggaran Kode Etik Bawaslu Provinsi Gorontalo.
} 
DKPP ialah memutus pelanggaran kode etik penyelenggara Pemilu dan memberikan sanksi kepada Penyelenggara Pemilu yang terbukti melanggar kode etik. ${ }^{11}$ Adapun sanksi yang dapat dijatuhkan oleh DKPP terhadap teradu ialah teguran tertulis, pemberhentian sementara atau pemberhentian tetap. ${ }^{12}$

\section{Rumusan Masalah}

Penulis merumuskan beberapa permasalahan, yakni tentang apakah asas ultra petita dalam memutus pelanggaran kode etik oleh KPU dan Bawaslu yang digunakan oleh DKPP tidak bertentangan dengan asas hukum positif yang berlaku. Selanjutnya apa yang menjadi akibat hukum putusan DKPP yang menerapkan asas ultra petita.

\section{Metode}

Penelitian ini merupakan penelitian hukum normatif, dengan menggunakan beberapa pendekatan hukum menurut Peter Mahmud Marzuki, antara lain: pendekatan perundang-undangan (statute approach), pendekatan kasus (case approach) dan pendekatan konseptual (conceptual approach). ${ }^{13}$ Penelitian hukum normatif bahan pustaka merupakan bahan dasar yang dalam ilmu penelitian umumnya disebut bahan hukum sekunder. Teknik pengumpulan bahan hukum dalam sebuah penelitian normatif dilakukan dengan cara telaah arsip, dokumen perundang-undangan atau studi pustaka seperti buku-buku, jurnal, tesis, disertasi atau publikasi hasil penelitian lainnya. Teknik analisis bahan hukum yang digunakan dalam penelitian ini adalah preskriptif-analitis.

\footnotetext{
${ }_{11}$ Pasal 159 ayat (2) huruf c dan d Undang-Undang Nomor 7 Tahun 2017 tentang Penyelenggaraan Pemilihan Umum

${ }^{12}$ Pasal 458 ayat (12) UU Pemilu dan Pasal 37 ayat (4) Peraturan DKPP Nomor 3 Tahun 2017.

13 Peter Mahmud Marzuki. (2005). “Penelitian Hukum edisi Revisi”. Surabaya: Prenadamedia. Hal. 136176
} 


\section{Asas Ultra Petita Dalam Putusan DKPP Berdasarkan Undang-Undang Nomor}

\section{Tahun 2017 Tentang Penyelenggara Pemilihan Umum.}

Dalam pengertian konseptual kelembagaan DKPP mempunyai kedudukan sebagai lembaga peradilan etika, hal ini pernah dikemukakan oleh Jimly Asshiddique. Meskipun berdiri dengan nama DKPP, tanpa menggunakan istilah pengadilan, tetapi pada hakikatnya kedudukan, tugas, dan kewenangannya, lembaga ini benar-benar merupakan lembaga peradilan etik. Lanjutnya, Bahkan pada awal pembentukannya, DKPP dapat dikatakan sebagai lembaga Pengadilan Etik pertama di dunia dan tentunya sebagai lembaga Pengadilan Etik pertama di Indonesia. ${ }^{14}$

DKPP berdasarkan Pasal 159 ayat (1) UU Pemilu mempunyai tugas sebagai berikut:

a. Menerima aduan dan/atau laporan dugaan adan ya pelanggaran kode etik yang dilakukan oleh penyelenggara Pemilu; dan

b. Melakukan penyelidikan dan verifikasi, serta pemeriksaan atas aduan dan/atau laporan dugaan adanya pelanggaran kode etik yang dilakukan oleh Penyelenggara Pemilu.

Dalam Pasal 159 ayat (2) DKPP berwenang:

a. Memanggil Penyelenggara Pemilu yang diduga melakukan pelanggaran kode etik untuk memberikan penjelasan dan pembelaan;

b. Memanggil pelapor, saksi, dan/atau pihak lain yang terkait unhrk dimintai keterangan, termasuk untuk dimintai dokumen atau bukti lain;

c. Memberikan sanksi kepada penyelenggara pemilu yang terbukti melanggar kode etik; dan

d. Memutus pelanggaran kode etik.

DKPP berkewajiban menerapkan prinsip menjaga keadilan, kemandirian, imparsialitas, dan transparansi; menegakkan kaidah atau norma etika yang berlaku bagi Penyelenggara Pemilu; bersikap netral, pasif dan tidak memanfaatkan kasus yang timbul untuk popularitas pribadi; dan menyampaikan putusan kepada pihak terkait untuk ditindaklanjuti. ${ }^{15}$ DKPP merupakan lembaga yang bertugas menangani pelanggaran kode etik penyelenggara Pemilu.

Pelanggaran kode etik penyelenggara Pemilu merupakan pelanggaran terhadap etika penyelenggara Pemilu yang berdasarkan sumpah dan/atau janji sebelum menjalankan

\footnotetext{
${ }^{14}$ Jimly Asshiddique. (2014). "Peradilan Etik dan Etika Konstitusi (Perspektif Baru tentang "Rule of Law and Rule of Ethics \& Constitutional Law and Constitutional Ethics). Jakarta: Sinar Grafika. Hal. 269

${ }^{15}$ Pasal 159 ayat (3) Undang-Undang Nomor 17 Tahun 2017 Tentang Penyelenggara Pemilihan Umum
} 
tugas sebagai penyelenggara Pemilu. ${ }^{16}$ Adapun mekanisme penyelesaian pelanggaran kode etik penyelenggara Pemilu di DKPP antara lain sebagai berikut ${ }^{17}$ :

1. Pengaduan tentang dugaan adanya pelanggaran kode etik Penyelenggara Pemilu diajukan secara tertulis oleh Penyelenggara Pemilu, Peserta Pemilu, tim kampanye, masyarakat, dan/atau pemilih dilengkapi dengan identitas pengadu kepada DKPP;

2. DKPP melakukan verifikasi dan penelitian administrasi terhadap pengaduan;

3. DKPP menyampaikan panggilan pertama kepada Penyelenggara Pemilu 5 (lima) hari sebelum melaksanakan sidang DKPP;

4. Dalam hal Penyelenggara Pemilu yang diadukan tidak memenuhi panggilan pertama, DKPP menyampaikan panggrlan kedua 5 (lima) hari sebelum melaksanakan sidang DKPP;

5. Dalam hal DKPP telah 2 (dua) kali melalrukan panggilan dan Penyelenggara Pemilu tidak memenuhi panggilan tanpa alasan yang dapat diterima, DKPP dapat segera membahas dan menetapkan putusan tanpa kehadiran Penyelenggara Pemilu yang bersangkutan;

6. Penyelenggara Pemilu yang diadukan harus datang sendiri dan tidak dapat menguasakan kepada orang lain;

7. Pengadu dan Penyelenggara Pemilu yang diadukan dapat menghadirkan saksi-saksi dalam sidang DKPP;

8. Pengadu dan Penyelenggara Pemilu yang diadukan mengemukakan alasan pengaduan atau pembelaan di hadapan sidang DKPP;

9. Saksi dan/ atau pihak lain yang terkait memberikan keterangan di hadapan sidang DKPP, termasuk untuk dimintai dokumen atau alat bukti lainnya;

10. DKPP menetapkan putusan setelah melakukan penelitian dan/atau verifikasi terhadap pengaduan tersebut, mendengarkan pembelaan dan keterangan saksi, serta mempertimbangkan bukti lainnya;

11. Putusan DKPP berupa sanksi atau rehabilitasi diambil dalam rapat pleno DKPP;

12. Sanksi dapat berupa teguran tertulis, pemberhentian sementara, atau pemberhentian tetap untuk Penyelenggara Pemilu;

13. Putusan DKPP bersifat final dan mengikat;

14. Penyelenggara Pemilu wajib melaksanakan putusan DKPP.

Kewenangan DKPP merupakan kewenangan atribusi yang diberikan oleh undangundang dalam hal ini ialah Pasal 159 UU Pemilu. Kewenangan sering disejajarkan dengan istilah wewenang. Istilah wewenang digunakan dalam bentuk kata benda dan sering disejajarkan dengan istilah "bevoegheid" dalam istilah hukum Belanda. Menurut Phillipus M. Hadjon, jika dicermati ada sedikit perbedaan antara istilah kewenangan dengan istilah "bevoegheid". Perbedaan tersebut terletak pada karakter hukumnya.

16 Pasal 456 Undang-Undang Nomor 17 Tahun 2017 Tentang Penyelenggara Pemilihan Umum 17 Pasal 458 Undang-Undang Nomor 17 Tahun 2017 Tentang Penyelenggara Pemilihan Umum 
Istilah "bevoegheid" digunakan dalam konsep hukum publik maupun dalam hukum privat. Dalam konsep hukum kita istilah kewenangan atau wewenang seharusnya digunakan dalam konsep hukum publik. ${ }^{18}$

Kewenangan atribusi DKPP dalam menyelesaikan pelanggaran etik Penyelenggara Pemilu diberikan batasan oleh UU Pemilu. Batasan kewenangan DKPP ialah dalam hal pemberian putusan yang di dalamnya berisi sanksi jika terbukti teradu melanggar kode etik Penyelenggara Pemilu. Sanksi yang ditentukan dalam UU Pemilu ialah ${ }^{19}$ :
a. Teguran tertulis;
b. Pemberhentian sementara; atau
c. Pemberhentian tetap.

Sifat final dan mengikat dari putusan DKPP haruslah dimaknai final dan mengikat bagi Presiden, KPU, KPU Provinsi, KPU Kabupaten/Kota, maupun Bawaslu dalam melaksanakan putusan DKPP. Adapun keputusan Presiden, KPU, KPU Provinsi, KPU Kabupaten/Kota, maupun Bawaslu adalah merupakan keputusan pejabat TUN yang bersifat konkrit, individual, dan final yang dapat menjadi objek gugatan di peradilan TUN. Apakah peradilan TUN akan memeriksa dan menilai kembali putusan DKPP yang menjadi dasar keputusan Presiden, KPU, KPU Provinsi, KPU Kabupaten/Kota, maupun Bawaslu, hal tersebut adalah merupakan kewenangan peradilan TUN. Dengan demikian putusan final dan mengikat yang dimaksud dalam Undang-Undang a quo haruslah dimaknai final dan mengikat bagi Presiden, KPU, KPU Provinsi, KPU Kabupaten/Kota, maupun Bawaslu yang melaksanakan Putusan DKPP.

DKPP merupakan lembaga peradilan etik Penyelenggara Pemilu, sehingga putusan yang dijatuhkan terhadap dugaan pelanggaran kode etik Penyelenggara Pemilu haruslah sesuai dengan kewenangan atribusi yang diberikan oleh UU Pemilu. Dengan demikian DKPP sebagai organ tata usaha negara yang bukan lembaga peradilan, namun sebagai lembaga peradilan etik dalam menyelesaikan pelanggaran kode etik

\footnotetext{
18 Philipus M. Hadjon. (Tanpa Tahun). Makalah: “Tentang Wewenang”. Surabaya: Universitas Airlangga. Hal. 20

19 Pasal 458 ayat (12) Undang-Undang Nomor 17 Tahun 2017 Tentang Penyelenggara Pemilihan Umum
} 
penyelenggara Pemilu harus sesuai dengan kewenangan atribusi yang telah digariskan oleh UU Pemilu.

Kewenangan DKPP dikaitakan dengan teori kepastian hukum, menurut Suseno kepastian hukum diartikan sebagai kejelasan norma, sehingga dapat dijadikan pedoman bagi masyarakat yang diikenakan peraturan itu. Pengertian kepastian hukum itu dapat dimaknai bahwa ada kejelasan dan ketegasan terhadap berlakunya hukum di masyarakat. Hal ini tidak menimbulkan banyak salah tafsir. Kepastian dapat pula mengandung arti yakni pertama, adanya kejelasan, kedua tidak menimbulkan multi tafsir atau keraguan, ketiga tidak menimbulkan kontradiktif, keempat dapat dilaksanakan.

Sehingga, kewenangan atribusi DKPP yang diberikan oleh UU Pemilu telah menjamin kepastian hukum terhadap penyelesaian dugaan pelanggaran kode etik. Kepastian hukum kewenangan DKPP meliputi penyelesaian pelanggaran kode etik yang berbentuk putusan yang memuat sanksi teguran tertulis, pemberhentian sementara atau pemberhentian tetap kepada Penyelenggara Pemilu. Batasan demikian telah memberikan kepastian hukum, namun apabila DKPP memutus dugaan pelanggaran Pemilu lebih dari kewenangan atribusi yang diberikan oleh UU Pemilu, maka DKPP telah melampaui kewenangannya (detournement de pouvoir).

Melampaui kewenangannya sebagai lembaga peradilan etika di sini berarti DKPP telah memutus dan menjatuhkan amar putusan di luar batasan yang telah ditentukan oleh UU Pemilu. Atau dengan kata lain, DKPP telah menerapkan asas ultra petita. Asas Ultra petita menurut I.P.M. Ranuhandoko adalah melebihi yang diminta. ${ }^{20}$ Yaitu penjatuhan putusan atas perkara yang tidak dituntut atau mengabulkan lebih daripada yang diminta. Sejalan dengan pernyataan tersebut asas Ultra petita menurut Yahya Harahap, hakim yang mengabulkan tuntutan melebihi posita maupun petitum gugatan, dianggap telah melampaui wewenang atau ultra vires, yakni bertindak melampaui wewenangnya. Apabila putusan mengandung ultra petita, maka putusan tersebut

20 IPM Ranuhandoko. (2000). “Terminologi Hukum”. Jakarta: Sinar Grafika. Hal. 522 
harus dinyatakan cacat meskipun hal itu dilakukan hakim dengan itikad baik (good faith) maupun sesuai dengan kepentingan umum (public interest). ${ }^{21}$

Dari uraian di atas, jelaslah bahwa DKPP mempunyai kewenangan atribusi yang diberikan oleh UU Pemilu. Namun, apabila DKPP memutus dan menjatuhkan sanksi di luar yang menjadi kewenangannya dalam UU Pemilu. DKPP telah melampaui kewenangannya (detournement de pouvoir) dan apabila melampaui kewenangan tersebut di luar apa yang dimintakan oleh pengadu maka DKPP telah menerapkan asas ultra petita. Padahal, DKPP bukan lembaga peradilan melainkan lembaga peradilan etik penyelenggara pemilu yang merupakan organ tata usaha negara.

\section{Asas Ultra Petita dalam Putusan DKPP Berdasarkan Peraturan DKPP Nomor 3}

\section{Tahun 2017 tentang Pedoman Beracara Kode Etik Penyelenggara Pemilu}

Berdasarkan teori kewenangan dikaitkan dengan kewenangan DKPP dalam menyelesaikan dugaan pelanggaran kode etik penyelenggara Pemilu yang diatur dalam Peraturan DKPP No 3 Tahun 2017. Peraturan tersebut merupakan turunan dari UU Pemilu yang telah memberikan kewenangan atribusi kepada DKPP untuk menyelesaikan dugaan pelanggaran kode etik penyelenggara Pemilu. Tentu, konsekuensi logis dari peraturan yang menjalankan/pelaksana induknya (UU Pemilu), Peraturan DKPP No 3 Tahun 2017 merupakan bentuk pengejawantahan/penjabaran kewenangan atribusi DKPP dalam menyelesaikan dugaan pelanggaran kode etik penyelenggara Pemilu.

Analisis pertentangan kewenangan DKPP dalam menerapkan asas ultra petita dalam menyelesaikan dugaan pelanggaran kode etik perlu dilihat lebih mendalam dalam Peraturan DKPP No 3 Tahun 2017. Peraturan ini menjadi hukum formil/hukum acara kewenangan atribusi DKPP. Dalam Pasal 37 ayat (3) Peraturan DKPP No 3 Tahun 2017, DKPP diberikan batasan sesuai dengan UU Pemilu. Bahwa DKPP dapat menjatuhkan amar putusan yang meliputi:

a. Pengaduan dan/atau Laporan tidak dapat diterima;

b. Teradu dan/atau Terlapor terbukti melanggar; atau

21 Yahya Harahap. (2008). "Hukum Acara Perdata Tentang Gugatan, Persidangan, Penyitaan, Pembuktian, dan Putusan Pengadilan. Jakarta: Sinar Grafika. Hal. 801 
c. Teradu dan/atau Terlapor tidak terbukti melanggar.

Dalam hal amar putusan menyatakan Teradu dan/atau Terlapor terbukti melanggar, DKPP menjatuhkan sanksi berupa 22 :

a. teguran tertulis;

b. pemberhentian sementara; atau

c. pemberhentian tetap.

Dalam hal amar putusan DKPP menyatakan Pengaduan dan/atau Laporan tidak terbukti, DKPP merehabilitasi Teradu dan/atau Terlapor. Dalam hal Pengadu dan/atau Pelapor atau Pihak Terkait yang merupakan Penyelenggara Pemilu terbukti melanggar kode etik dalam pemeriksaan persidangan, DKPP dapat memerintahkan jajaran KPU dan/atau Bawaslu untuk melakukan pemeriksaan. ${ }^{23}$ Sehingga, dalam konteks ini penulis berpendapat bahwa penerapan asas ultra petita tidak melampaui kewenangan (detournement de pouvoir) DKPP sepanjang sesuai dengan batasan yang ditentukan oleh UU Pemilu dan hukum acaranya dalam Peraturan DKPP No 3 Tahun 2017.

Asas ultra petita berarti melampaui apa yang dimintakan oleh pemohon dalam hal ini pengadu dalam dugaan pelanggaran kode etik penyelenggara Pemilu. Dengan demikian, apabila yang tidak diminta oleh pemohon kemudian diputus oleh DKPP (menerapkan asas ultra petita), sepanjang sesuai dengan batasan putusan yang dapat dijatuhkan oleh DKPP dalam UU Pemilu dan Peraturan DKPP No 3 Tahun 2017. Maka DKPP tidak melampaui kewenangannya (detournement de pouvoir).

Namun, apabila putusan DKPP menjatuhkan yang tidak diminta oleh pemohon kemudian diputus oleh DKPP melebihi batasan yang ditentukan oleh UU Pemilu dan Peraturan DKPP No 3 Tahun 2017 maka DKPP telah melampaui kewenangannya (detournement de pouvoir) sebagai organ tata usaha negara. Berikut digambarkan oleh penulis mengenai analisis kewenangan DKPP dalam memutus dugaan pelanggaran kode etik penyelenggara Pemilu:

22 Pasal 37 ayat (4) Peraturan DKPP No 3 Tahun 2017

23 Pasal 37 ayat (5) dan ayat (6) Peraturan DKPP No 3 Tahun 2017 
Gambar 5.1.

Kewenangan DKPP Dalam Memutus Dugaan Pelanggaran Kode Etik Penyelenggara Pemilu

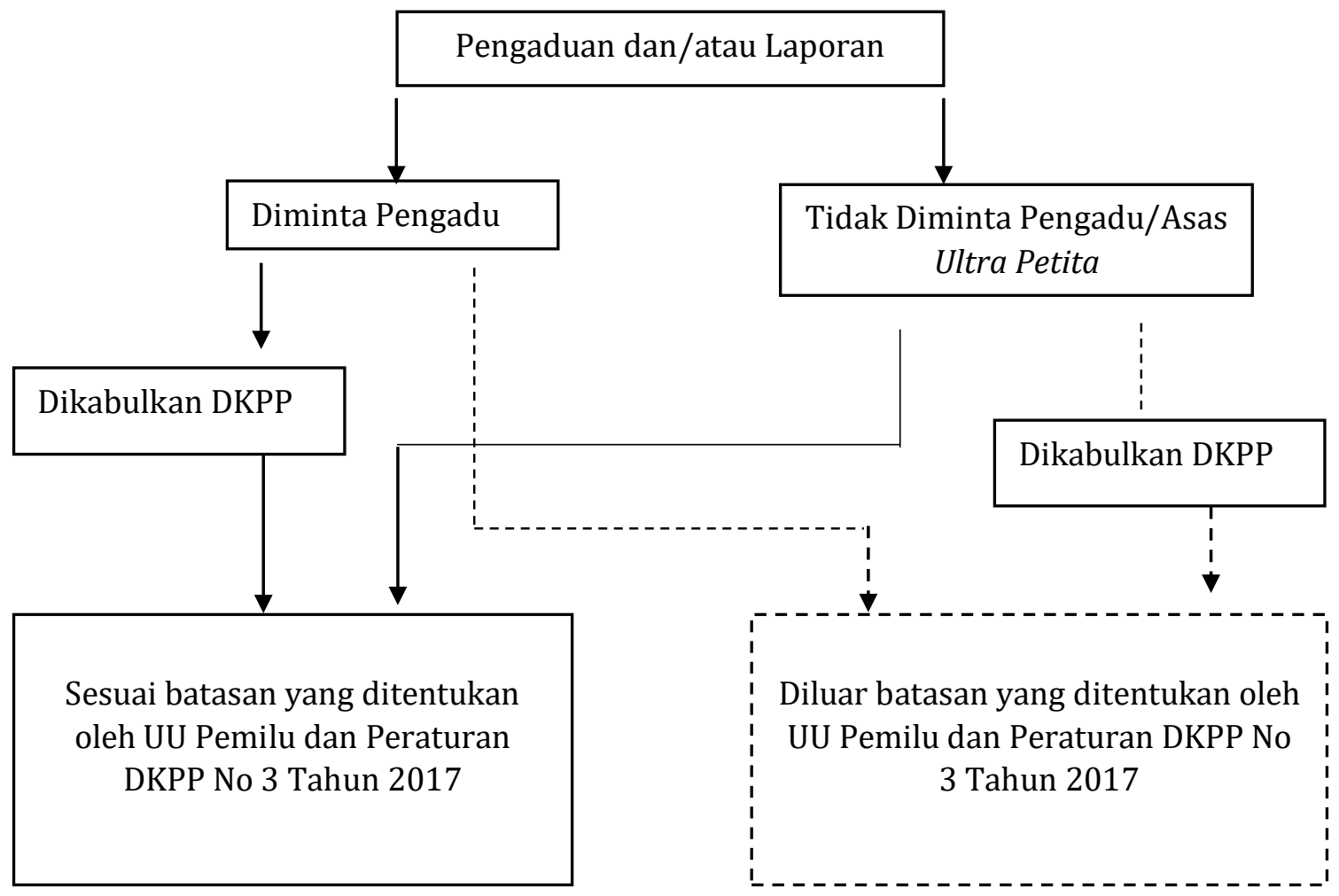

Sumber Bahan Hukum primer (diolah: 2019)

\section{Akibat Hukum Putusan DKPP yang Menerapkan Asas Ultra Petita}

Sebagai organ tata usaha negara, DKPP harus mentaati peraturan perundangundangan yang berlaku. Khususnya mengenai kewenangan atribusi DKPP yang ditentukan dalam UU Pemilu. Walaupun DKPP merupakan organ tata usaha negara, putusan DKPP terhadap pelanggaran kode etik penyelenggara Pemilu bukan merupakan Keputusan Tata Usaha Negara. DKPP merupakan lembaga pengadilan etika, untuk itu DKPP tidak pro aktif melainkan bersifat pasif. Kendati demikian DKPP juga menjalankan fungsi edukasi kepada khalayak untuk menjelaskan peran DKPP melalui sosialisasi kode etik.

Putusan DKPP final dan mengikat, tidak ada lembaga peradilan dibawah Mahkamah Agung yang bisa mengkoreksi Putusan DKPP. Yang tidak final dan mengikat adalah Keputusan KPU dan Bawaslu, karena bisa dijadikan objek sengketa Tata Usaha Negara (TUN), bukan putusan DKPP. 
Putusan DKPP merupakan final dan mengikat bagi bagi Presiden, KPU, KPU Provinsi, KPU Kabupaten/Kota, dan Bawaslu. Putusan DKPP bukan merupakan objek sengketa PTUN, karena bukan keputusan tata usaha negara. Berdasarkan Pasal 1 angka 7 Undang-Undang Nomor 30 Tahun 2014 tentang Administrasi Pemerintahan (untuk selanjutnya disebut UU Administrasi Pemerintahan), "Keputusan Administrasi Pemerintahan yang selanjutnya disebut Keputusan Tata Usaha Negara atau Keputusan Administrasi Negara yang selanjutnya disebut Keputusan adalah ketetapan tertulis yang dikeluarkan oleh Badan dan/atau Pejabat Pemerintahan dalam penyelenggaraan Pemerintahan."

Dengan berlakunya UU No 30 Tahun 2014, Keputusan Tata Usaha Negara sebagaimana dimaksud dalam UU No 5 Tahun 1986 sebagaimana telah diubah dengan UU No 9 Tahun 2004 dan UU No 51 Tahun 2009 harus dimaknai sebagai:

a) penetapan tertulis yang juga mencakup tindakan faktual;

b) keputusan Badan dan/atau Pejabat Tata Usaha Negara di lingkungan eksekutif, legislatif, yudikatif, dan penyelenggara negara lainnya;

c) berdasarkan ketentuan perundang-undangan dan AUPB;

d) bersifat final dalam arti lebih luas;

e) keputusan yang berpotensi menimbulkan akibat hukum; dan/atau

f) keputusan yang berlaku bagi warga masyarakat.

Putusan DKPP merupakan putusan final dan mengikat yang menjadi landasan untuk Penyelenggara Pemilu (KPU dan Bawaslu) menindaklanjuti pemberhentian anggota Penyelenggara Pemilu. Tindak lanjut pemberhentian Penyelenggara Pemilu merupakan Keputusan Tata Usaha Negara yang dikeluarkan oleh Penyelenggara Pemilu (KPU dan Bawaslu), yang merupakan objek sengketa tata usaha negara (Pengadilan Tata Usaha Negara). Terkait dengan hal itu, maka putusan DKPP sebagai runtutan/salah satu proses yang mendasari dibentuknya Keputusan Tata Usaha Negara (pemberhentian anggota KPU atau Bawaslu yang terbukti melakukan pelanggaran kode etik) maka putusan DKPP tidak boleh melampaui kewenangan atribusinya yang diberikan oleh UU Pemilu.

Karena apabila putusan DKPP melampaui kewenangan atribusinya, maka akan melanggar asas detournement de pouvoir. Sehingga, putusan DKPP haruslah sesuai dengan kewenangannya tidak boleh malampaui kewenangan yang diberikan oleh UU 
Pemilu. Akibat hukum putusan DKPP yang melampaui kewenangannya ialah Keputusan Tata Usaha Negara yang dikeluarkan oleh Penyelenggara Pemilu berupa mengandung cacat hukum, dan Keputusan Tata Usaha Negara tersebut batal atau tidak sah. Berikut ini penulis menggambarkan akibat hukum putusan DKPP yang menerapkan asas ultra petita:

Gambar 6.1.

Akibat Hukum Putusan DKPP yang Menerapkan Asas Ultra Petita

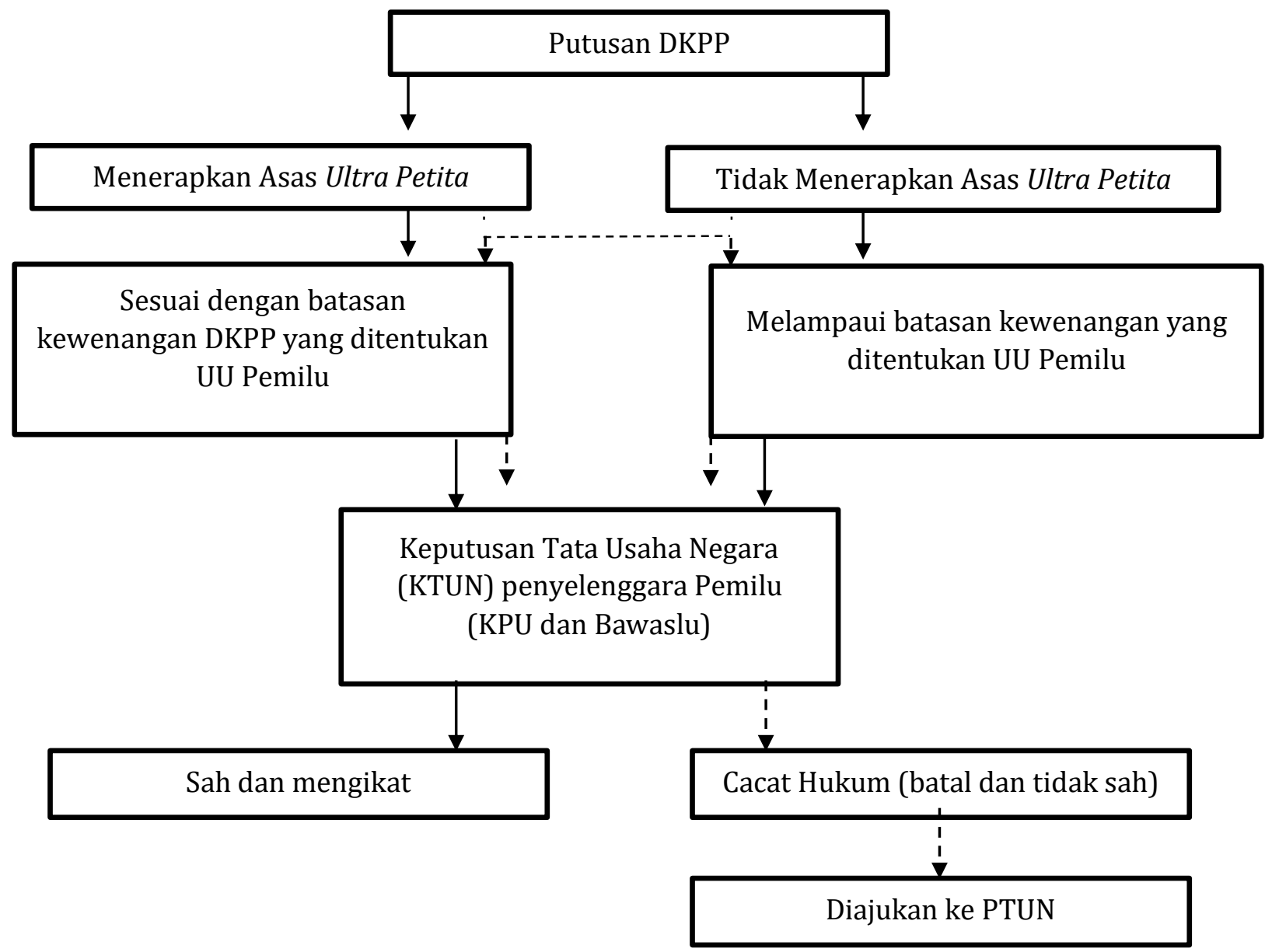

Sumber Bahan Hukum Primer (diolah: 2019)

\section{Kesimpulan}

Penggunaan asas ultra petita oleh DKPP dalam memutus pelanggaran kode etik oleh penyelenggara Pemilu (KPU dan Bawaslu) tidak bertentangan dengan asas hukum positif yang berlaku, karena telah ditentukan batasan kewenangan putusan DKPP dalam UU Pemilu. Namun, apabila penggunaan asas ultra petita oleh DKPP melebihi batasan kewenangan putusan DKPP dalam UU Pemilu, maka putusan DKPP 
bertentangan dengan asas hukum positif yang berlaku yaitu asas tidak tidak menyalahgunakan kewenangan (detournement de pouvoir).

Putusan DKPP merupakan putusan yang bersifat final dan mengikat. Terdapat dua akibat hukum putusan DKPP yang menerapkan asas ultra petita. Pertama, putusan DKPP mengakibatkan Keputusan Tata Usaha Negara (KTUN) penyelenggara Pemilu (KPU dan Bawaslu) sah dan mengikat ialah putusan DKPP yang menerapkan asas ultra petita, dan sesuai dengan batasan kewenangan DKPP yang ditentukan UU Pemilu. Batasan kewenangan yang ditentukan UU Pemilu ialah penjatuhan sanksi teguran tertulis, pemberhentian sementara, atau pemberhentian tetap. Kedua, putusan DKPP mengakibatkan Keputusan Tata Usaha Negara (KTUN) penyelenggara Pemilu (KPU dan Bawaslu) cacat hukum (batal dan tidak sah) ialah putusan DKPP yang menerapkan asas ultra petita, dan putusan DKPP melampaui kewenangan DKPP yang ditentukan UU Pemilu. Meliputi penjatuhan sanksi diluar sanksi sanksi teguran tertulis, pemberhentian sementara, atau pemberhentian tetap, yang tercantum dalam UU Pemilu.

\section{Referensi}

Asshiddiqie, Jimly. (2014). "Peradilan Etik dan Etika Konstitusi (Perspektif Baru tentang 'Rule of Law and Rule of Ethics' \& Constitutional Law dan Constitutional Ethics']". Jakarta: Sinar Grafika.

Chandranegara, Ibnu Sina. "Ultra petita Dalam Pengujian Undang-undang dan Jalan Mencapai Keadilan Konstitusional". Jurnal Konstitusi, Vol 9 No 1, Maret 2012.

DKPP RI. Ida Budiati: DKPP Dikonstruksi Sebagai Lembaga Pengadilan Etika, (Online) http://dkpp.go.id/ida-budiati-dkpp-dikonstruksi-sebagai-lembaga-pengadilanetika/. Diakses pada tanggal 26 Juni 2019

Harahap, Yahya. (2008). "Hukum Acara Perdata tentang Gugatan, Persidangan, Penyitaan, Pembuktian, dan Putusan Pengadilan". Jakarta: Sinar Grafika Marzuki, Peter Mahmud. (2005). "Penelitian Hukum Edisi Revisi". Surabaya: Prenadamedia Group. 
M. Hadjon, Philipus. (Tanpa tahun). Makalah: “Tentang Wewenang”, Surabaya: Universitas Airlangga.

Ranuhandoko, IPM. (2000). “Terminologi Hukum”. Jakarta: Sinar Grafika.

Soekanto, Soerdjono, dan Mamudji, Sri. (2006). "Penelitian Hukum Normatif Tinjauan Singkat". Jakarta: Rajawali Pers

\section{Peraturan Perundang-undangan}

Undang-Undang Dasar Negara Republik Indonesia Tahun 1945.

Undang-Undang Nomor 5 Tahun 1986 tentang Peradilan Tata Usaha Negara (Lembaran Negara Republik Indonesia Tahun 1986 Nomor 77) sebagaimana telah diubah terakhir dengan Undang-Undang Nomor 51 Tahun 2009 tentang Perubahan Kedua atas Undang-Undang Nomor 5 Tahun 1986 tentang Peradilan Tata Usaha Negara (Lembaran Negara Republik Indonesia Tahun 2009 Nomor 160, Tambahan Lembaran Negara Republik Indonesia Nomor 5079).

Undang-Undang Nomor 30 Tahun 2014 tentang Administrasi Pemerintahan (Lembaran Negara Republik Indonesia Tahun 2014 Nomor 292, Tambahan Lembaran Negara Republik Indonesia Nomor 5601).

Undang-Undang Nomor 17 Tahun 2017 tentang Penyelenggara Pemilihan Umum (Lembaran Negara Republik Indonesia Tahun 2017 Nomor 182, Tambahan Lembaran Negara Republik Indonesia Nomor 6109).

Peraturan DKPP Nomor 3 tahun 2017 tentang Pedoman Beracara Kode Etik Penyelenggara Pemilihan Umum (Berita Negara Republik Indonesia Tahun 2017 Nomor 1404).Titin anidyajati, dkk. (2015). Konstitusionalitas Norma Sanksi Pidana sebagai Ultimum Remedium dalam Pembentukan Perundang-undangan, Jurnal Konstitusi, Volume 12, Nomor 4, Desember. 